\title{
Molecular-genetic analysis of Malus sieversii - comparison of Dzungarian populations in situ and ex situ
}

\author{
L. Shadmanova ${ }^{1,2}$, G. Sitpayeva ${ }^{2}$, G. Mukanova ${ }^{2}$, N. Friesen ${ }^{3,4}$ \\ ${ }^{1}$ Al-Farabi Kazakh National University, Timiryazev str. 71, Almaty, 050038, Republic of Kazakhstan. \\ E-mail: laura_shadmanova@mail.ru \\ ${ }^{2}$ Institute of botany and phytointroduction, Timiryazev str. 36 d, Almaty, 050040, Republic of Kazakhstan. \\ E-mail:sitpaeva@mail.ru \\ ${ }^{3}$ Botanical Garden of the University of Osnabruck, Albrechtstr. 29, Osnabruck, 490776, Germany. \\ E-mail: nikolai.friesen@biologie.uni-osnabrueck.de
}

${ }^{4}$ I. M. Sechenov First Moscow State Medical University Ministry of Health of the Russian Federation, Department of Pharmaceutical and Natural Sciences, Izmailovsky Boulevard, 8, Moscow, 105043, Russian Federation

Keywords: Clone-varieties of Sievers apple tree, ISSR-PCR, ITS, Malus sieversii, $r p s 16$ intron, $\operatorname{trn} \mathrm{L}$ intron, $\operatorname{trn} \mathrm{L}-\operatorname{trn} \mathrm{F}$ spacer.

Summary. Malus sieversii (Ledeb.) M. Roem. is recognized as the ancestor of the cultivated apple tree. It has a valuable gene pool, and in the last decades, it becomes endangered in Kazakhstan. The genetic diversity of 13 clonevarieties of Sievers apple tree (Malus sieversii) of Dzungarian population from the introduction collection of the Main Botanical Garden in Almaty (Kazakhstan) and 31 samples from three natural populations were assessed using eight polymorphic ISSR markers. The phylogenetic relationship of the clone-varieties with the natural population was estimated using ribosomal (ITS) and chloroplast DNA ( $r p s 16$ intron, $\operatorname{trn} \mathrm{L}$ intron, $\operatorname{trn} \mathrm{L}-\operatorname{trn} \mathrm{F})$. The data revealed a high genetic diversity of various clones and samples of Sievers apple tree of the Dzungarian populations. As a result of phylogenetic and cluster analysis the studied clones and samples of $M$. sieversii from natural populations formed a cluster, samples of supposedly hybrid origin formed 2 clusters, and no clustering was detected depending on geographical distance. The data demonstrate that there is an active information exchange between the populations.

\section{Молекулярно-генетический анализ Malus sieversii - сравнение Джунгарской популяции in situ и ex situ}

\author{
Л. Ш. Шадманова ${ }^{1,2}$, Г. Т. Ситпаева 2 , Г. С. Муканова 2 Н. В. Фризен ${ }^{3,4}$ \\ ${ }^{1}$ Казахский национальный университет им. аль-Фараби, ул. Тимирязева, 71, г. Алматы, 050038, Казахстан \\ ${ }^{2}$ Институт ботаники и фитоинтродукиии, ул. Тимирязева, 36д, г. Алматы, 050040, Казахстан \\ ${ }^{3}$ Ботанический сад Университета г. Оснабрюк, Альбрехитрассе, 29, г. Оснабрюк, 050040, Германия \\ ${ }^{4}$ Первый Московский государственный медицинский университет им. И. М. Сеченова, \\ Измайловский бульвар, 8, г. Москва, 105043, Россия
}

Ключевые слова: генетическое разнообразие, рибосомальная и хлоропластная ДНК, сорт-клоны яблони Сиверса, ISSR-PCR, ITS, Malus sieversii, $r p s 16$ intron, $\operatorname{trn} \mathrm{L}$ intron, $\operatorname{trn} \mathrm{L}-\operatorname{trn} \mathrm{F}$ spacer. 


\begin{abstract}
Aннотация. Malus sieversii (Ledeb.) M. Roem. (яблоня Сиверса), признанная основным родоначальником культурной яблони и обладающая ценным генофондом, в последние десятилетия находится под угрозой исчезновения в Казахстане. Генетическое разнообразие 13 сортов-клонов яблони Сиверса джунгарской популяции из интродукционной коллекции Главного ботанического сада г. Алматы (Казахстан) и 31 образец из трех популяций Джунгарского Алатау были изучены с использованием 8 полиморфных межмикросаттеллитных маркеров (ISSR); филогенетическая связь сортов-клонов с природной популяцией оценивалась с помощью рибосомальной (ITS) и хлоропластной ДНК ( $r p s 16$ intron, $t r n \mathrm{~L}$ intron and $t r n \mathrm{~L}-t r n \mathrm{~F}$ spacer). В ходе работы выявлено высокое генетическое разнообразие как сорт-клонов, так и образцов M. sieversii, отобранных из природных популяций в горах Джунгарского Алатау. В результате филогенетического и кластерного анализов изученные сорт-клоны и образцы M. sieversii из природных популяций образовали 1 кластер, образцы предположительно гибридного происхождения образовали 2 кластер, при этом не выявлено какой-либо кластеризации в зависимости от географического положения. Данные показывают, что между популяциями идет активный генетический обмен.
\end{abstract}

\section{Introduction}

The territory of Kazakhstan is the northern margins of the Central Asian centre of origin of several plant species. In this geographical region, many economically valuable species are distributed, such as Malus sieversii (Ledeb.) M. Roem. Sievers apple tree (Vavilov, 1931; Luby et al., 2001; Dzhangaliev, 2003). This wild apple tree thrives in the montane and subalpine belts of the mountains at an altitude of 800 to $1700 \mathrm{~m}$. Some single specimens were found at an altitude of ca. $2200 \mathrm{~m}$. Occasionally it forms fruit forests (Dzhangaliev, 1977). Natural populations can be found in the mountainous regions of Kazakhstan, Kyrgyzstan, Uzbekistan, Western China, and Tajikistan (Luby et al., 2001; Cornille et al., 2012; Zhang et al., 2015). In Kazakhstan, it is common in Zailiysky Alatau, Dzungar Alatau, Kirghiz Alatau, Karatau, Talas Alatau. The northemost point of the distribution range in Kazakhstan is Tarbagatai. The largest natural populations of $M$. sieversii are found in the Kazakh part of the Dzungar Alatau (Dzhangaliev, 1977).

The first mention about apple forests on the current territory of Kazakhstan was found in the letters of J. Sievers (Sievers, 1796). Later Ledebour described his herbarium vouchers of the apple in 1830 as Sievers pear (Pyrus sieversii) (Ledebour, 1830 ) and in 1847, M. J. Roemer transferred the species to the genus Malus Mill. In the 60s of the last century, as a result of large-scale and detailed studies of wild fruit forests (Dzhangaliev, 1977), the uniqueness of the Sievers apple tree and its global significance was discovered. It was noted that the wild apple has significant ecological and biological functions, and due to its high fruit polymorphism, it serves as a vital source for plant breeding. Phylogenetic studies showed that $M$. sieversii is the ancestor of the cultivated apple tree and has a valuable gene pool for apple plant breeders (Zhou, Li, 2000; Robinson et al., 2001; Forsline et al., 2003; Juniper, Mabberley, 2006). Malus sieversii was listed in the Red Book (Dzhangaliev et al., 1981; Isayev, 2014) and was registered in the International Red List in 2000 as vulnerable (VU) (IUCN, 2000).

Genetic reserves were allocated in natural cenoses as an in situ conservation approach, and a unique ex situ collection of trees was created in Main Botanical Garden of Almaty (MBG), Kazakhstan, to preserve the Sievers apple tree (Dzhangaliev, 1977). The collection of $M$. sieversii in the MBG was created during the past century from natural populations of the mountain forests of the Republic of Kazakhstan. They were selected based on valuable phenotypes from a practical point of view (taste, color and size of the fruit, etc.) (Dzhangaliev, 1977). Grafting from the selected phenotypes were graft on the rootstock of a Sievers apple tree grown from seeds of $M$. sieversii of unknown origin. Even though the species was taken under protection, the natural populations of $M$. sieversii of Kazakhstan with a wide range of genetic and phenotypic variations of characters are increasingly subjected to anthropogenic pressure and genetic erosion. Over the past decades, the distribution area of Sievers apple trees has decreased by $70 \%$ in Trans-Ili Alatau, and by $30 \%$ in Dzungarian Alatau (Dzhangaliyev, 2003).

The most important measures for their protection according to Dzhangaliyev and Salova (2007) are the restoration of the natural genetic structure of populations. This implies certainty of the origin of each seedling used in reforestation. The use of molecular methods enables the evaluation of the current state of the genetic diversity in this species, the genetic origin, and potential reintroduction in natural populations. Current studies of M. sieversii are of great importance both in natural populations (Zhang et al., 2007; Yan et al., 2008; 
Volk et al., 2009; Sitpaeva et al., 2016; Omasheva et al., 2017), and in artificial cenoses (Volk et al., 2005; Richards et al., 2009). Microsatellite (SSR) and inter-simple sequence repeat markers (ISSR) are widely used to detect DNA polymorphism and has become widespread in phylogenetic studies of apple trees and other plants (Gupta et al., 1994; Hokanson et al., 1998; Kutsev, 2009; Omasheva et al., 2015). Omasheva et al. (2015) revealed high levels of heterozygosity in four populations of East Kazakhstan of $M$. sieversii using SSRs.

The combination of nuclear and chloroplast sequence data can provide additional insights into the evolution of genomes, and is a powerful method for identifying hybrid plant origin (Smirnov, Friesen, 2006; Hurka et al., 2012).

For this study, the internal transcribed spacer (ITS) and three noncoding regions of chloroplasts (rps 16 intron, $\operatorname{trn} \mathrm{L}$ intron, $\operatorname{trn} \mathrm{L}-t r n \mathrm{~F}$ spacer) were analysed.

In this study, the genetic diversity of $M$. sieversii clone-varieties (sort-clones) of the Dzungarian populations from the living collection in the Main Botanical Garden of Almaty is compared with natural populations. The obtained data will be used to clarify the relationships between populations of Sievers apple tree. The results will be validated for the use of varieties in breeding and reintroduction into the natural habitat.

\section{Materials and Methods}

In this study, $13 M$. sieversii clone-varieties of the Dzungarian populations from the collection of the MBG in Almaty (Kazakhstan) were used. The trees were about 30 years old (Fig. 1). The studied clone-varieties differ in morphological characters. The grafted scions for the TM-1, TM-2, TM-5, TM-7, TM-8, TM-9 clone-varieties were selected from the Mushabai plot. They were located on the divide of the same name. For the clone-varieties TP-19, ТР-20, ТР-21, ТР-22, ТР-23, ТР-24, ТР25 grafts were obtained from the Pikhtovaya Gorge of the Dzungarian Alatau (Tab. 1). Leaves were also collected from 31 trees of different ages, selected based on different morphological features during expeditions to genetic reserves: Pikhtovaya, Mushabay and Krutoye in the Dzungarian Alatau. The GPS coordinates of each location were recorded for further research (Tab. 2). The collected material was dried on silica gel. DNA was isolated using the innuPREP Plant DNA kit (Analytik Jena, Germany), following the instruction of the manufacturer.

Table 1

Characteristics of Malus sieversii clone-varieties of the Main Botanical garden

\begin{tabular}{|l|c|c|l|l|}
\hline № & Code & $\begin{array}{c}\text { Clone- } \\
\text { varieties }\end{array}$ & $\begin{array}{c}\text { Rootstock collection } \\
\text { location }\end{array}$ & \multicolumn{1}{|c|}{ Description of clone-varieties } \\
\hline 1 & MS1 & TP-25 & $\begin{array}{l}\text { Pikhtovaya gorge, } \\
\text { Dzungar Alatau }\end{array}$ & $\begin{array}{l}\text { Height 6 m, sphere-shaped crown, large, round green } \\
\text { fruit with blurred red cover colour, sweet and sour, } \\
\text { they ripen at the end of September }\end{array}$ \\
\hline 2 & MS2 & TM-1 & $\begin{array}{l}\text { Mushabay plot } \\
\text { Dzungar Alatau }\end{array}$ & $\begin{array}{l}\text { Height 5-6 m, sphere-shaped crown, small light green } \\
\text { leaves, small sweet and sour fruit, they ripen in the first } \\
\text { decade of August }\end{array}$ \\
\hline 3 & MS3 & TM-2 & $\begin{array}{l}\text { Mushabay plot } \\
\text { Dzungar Alatau }\end{array}$ & $\begin{array}{l}\text { Height 5 m, spreading tent-shaped crown, small green } \\
\text { fruit that ripen in the first decade of August }\end{array}$ \\
\hline 5 & MS4 & TM-5 & $\begin{array}{l}\text { Mushabay plot } \\
\text { Dzungar Alatau }\end{array}$ & $\begin{array}{l}\text { Height 5 m, sphere-shaped crown, medium-sized } \\
\text { leaves, medium-sized, elongated, green fruit with red } \\
\text { stripes, sweet and sour, ripens at the end of July }\end{array}$ \\
\hline 6 & MS6 & TM-8 & $\begin{array}{l}\text { Mushabay plot } \\
\text { Dzungar Alatau }\end{array}$ & $\begin{array}{l}\text { Height 4 m, tent-shaped crown, narrow leaves on long } \\
\text { leaf stalks, flattened, small, costate astringent fruit, } \\
\text { ripen in the first decade of August }\end{array}$ \\
\hline 7 & Mzungar Alatau & $\begin{array}{l}\text { Height 5 m, sphere-shaped crown, small yellow, sour } \\
\text { fruit, ripen at the end of August }\end{array}$ \\
\hline 8 & MS8 & TM-9 & $\begin{array}{l}\text { Mushabay plot } \\
\text { Dzungar Alatau }\end{array}$ & $\begin{array}{l}\text { Height 4 m, spreading crown, narrow leaves large fruit, } \\
\text { tasteless or sweet, they ripen in the second decade of } \\
\text { August }\end{array}$ \\
\hline
\end{tabular}


Table 1 (end)

\begin{tabular}{|l|c|c|l|l|}
\hline № & Code & $\begin{array}{c}\text { Clone- } \\
\text { varieties }\end{array}$ & $\begin{array}{c}\text { Rootstock collection } \\
\text { location }\end{array}$ & \multicolumn{1}{|c|}{ Description of clone-varieties } \\
\hline 9 & MS9 & TP-20 & $\begin{array}{l}\text { Pikhtovaya gorge } \\
\text { Dzungar Alatau }\end{array}$ & $\begin{array}{l}\text { Height 5 m, tent-shaped crown, small fruit, which ripen } \\
\text { in the first decade of August }\end{array}$ \\
\hline 10 & MS10 & TP-21 & $\begin{array}{l}\text { Pikhtovaya gorge } \\
\text { Dzungar Alatau }\end{array}$ & $\begin{array}{l}\text { Height 5 m, spreading crown, large elongated leaves, } \\
\text { large green fruit with cover raspberry colour, sweet, } \\
\text { they ripen in the 1 decade of August }\end{array}$ \\
\hline 11 & MS11 & TP-22 & $\begin{array}{l}\text { Pikhtovaya gorge } \\
\text { Dzungar Alatau }\end{array}$ & $\begin{array}{l}\text { Height 4 m, sphere-shaped crown, medium thick } \\
\text { leaves, narrow leaves, small sour fruit, ripen at the end } \\
\text { of July }\end{array}$ \\
\hline 12 & MS12 & TP-23 & $\begin{array}{l}\text { Pikhtovaya gorge } \\
\text { Dzungar Alatau }\end{array}$ & $\begin{array}{l}\text { Height 4 m, sphere-shaped crown, large medium } \\
\text { elongated leaves, medium-sized sour fruit, ripen in the } \\
\text { second decade of August }\end{array}$ \\
\hline 13 & MS13 & TP-24 & $\begin{array}{l}\text { Pikhtovaya gorge } \\
\text { Dzungar Alatau }\end{array}$ & $\begin{array}{l}\text { Height 5 m, sphere-shaped crown, narrow, medium } \\
\text { thick leaves, small slightly sour fruit ripen in the first } \\
\text { decade of August }\end{array}$ \\
\hline
\end{tabular}

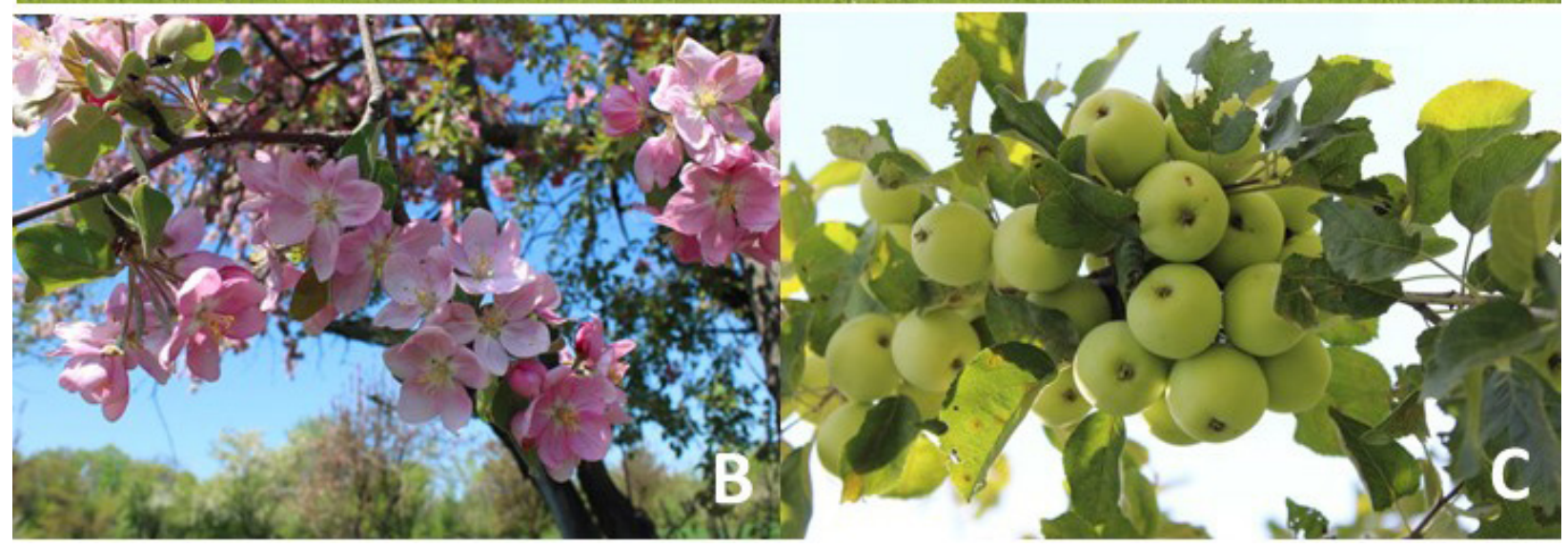

Fig. 1. Clone varieties of Malus sieversii in the collection of the Main Botanical Garden, Almaty: A - General view; $\mathrm{B}$ - Flowering branch of one of the variety clone; $\mathrm{C}$ - Branch with fruits. 
Table 2

Characteristics of the sampling site

\begin{tabular}{|c|c|c|c|c|}
\hline Populations & Location & $\begin{array}{l}\text { Sample } \\
\text { code }\end{array}$ & $\begin{array}{l}\text { Altitude of } \\
\text { explored } \\
\text { location, } \mathrm{m} \\
\text { above the sea } \\
\text { level } \\
\end{array}$ & Geographical coordinates \\
\hline \multirow{5}{*}{$\begin{array}{l}\text { Pop } 1 \\
\text { "P i k h t o v a y a" } \\
\text { Selection and genetic } \\
\text { wildlife reserve, } \\
\text { Dzungar Alatau }\end{array}$} & \multirow{5}{*}{$\begin{array}{l}\text { Along the Mushabay } \\
\text { water divide on the } \\
\text { left bank of the river } \\
\text { of Terekty }\end{array}$} & MS14 & 1139 & $45^{\circ} 24^{\prime} 13.3^{\prime \prime} \mathrm{N}, 80^{\circ} 23^{\prime} 46.6^{\prime \prime} \mathrm{E}$ \\
\hline & & MS15 & 1139 & $45^{\circ} 24^{\prime} 13.4^{\prime \prime} \mathrm{N}, 80^{\circ} 23^{\prime} 46.8^{\prime \prime} \mathrm{E}$ \\
\hline & & MS16 & 1140 & $45^{\circ} 24^{\prime} 13.4^{\prime \prime} \mathrm{N}, 80^{\circ} 23^{\prime} 46.9^{\prime \prime} \mathrm{E}$ \\
\hline & & MS17 & 1124 & $45^{\circ} 24^{\prime} 01.3^{\prime \prime} \mathrm{N}, 80^{\circ} 23^{\prime} 17.0^{\prime \prime} \mathrm{E}$ \\
\hline & & MS18 & 1139 & $45^{\circ} 24^{\prime} 15.2^{\prime \prime} \mathrm{N}, 80^{\circ} 23^{\prime} 45.6^{\prime \prime} \mathrm{E}$ \\
\hline \multirow{5}{*}{$\begin{array}{l}\text { Pop } 2 \\
\text { "Mushabay" } \\
\text { Selection and genetic } \\
\text { wildlife reserve, } \\
\text { Dzungar Alatau }\end{array}$} & \multirow{5}{*}{$\begin{array}{l}\text { Along the Mushabay } \\
\text { water divide } \\
\text { between the rivers } \\
\text { of Soldatskaya and } \\
\text { Pikhtovaya }\end{array}$} & MS19 & 1149 & $45^{\circ} 24^{\prime} 47.9^{\prime \prime} \mathrm{N}, 80^{\circ} 23^{\prime} 13.0^{\prime \prime} \mathrm{E}$ \\
\hline & & MS20 & 1140 & $45^{\circ} 24^{\prime} 52.7^{\prime \prime} \mathrm{N}, 80^{\circ} 23^{\prime} 15.7^{\prime \prime} \mathrm{E}$ \\
\hline & & MS21 & 1140 & $45^{\circ} 24^{\prime} 52.6^{\prime \prime} \mathrm{N}, 80^{\circ} 23^{\prime} 15.8^{\prime \prime} \mathrm{E}$ \\
\hline & & MS22 & 1145 & $45^{\circ} 23^{\prime} 49.1^{\prime \prime} \mathrm{N}, 80^{\circ} 23^{\prime} 14.6^{\prime \prime} \mathrm{E}$ \\
\hline & & MS23 & 1131 & $45^{\circ} 23^{\prime} 56.0^{\prime \prime} \mathrm{N}, 80^{\circ} 23^{\prime} 14.1^{\prime \prime} \mathrm{E}$ \\
\hline \multirow{21}{*}{$\begin{array}{l}\text { Pop } 3 \\
\text { "Krutoye" Selection } \\
\text { and Genetic wildlife } \\
\text { reserve, Dzungar } \\
\text { Alatau }\end{array}$} & \multirow{21}{*}{$\begin{array}{l}\text { South of the } \\
\mathrm{Z} \mathrm{h} \mathrm{u} \mathrm{n} \mathrm{h} \mathrm{h} \mathrm{r} \mathrm{e} \mathrm{k} \\
\text { settlement on the } \\
\text { right bank of the } \\
\text { Lepsa river }\end{array}$} & MS24 & 1488 & $45^{\circ} 33^{\prime} 21.8^{\prime \prime} \mathrm{N}, 80^{\circ} 43^{\prime} 48.5^{\prime \prime} \mathrm{E}$ \\
\hline & & MS25 & 1489 & $45^{\circ} 33^{\prime} 21.9^{\prime \prime} \mathrm{N}, 80^{\circ} 43^{\prime} 48.8^{\prime \prime} \mathrm{E}$. \\
\hline & & MS26 & 1489 & $45^{\circ} 33^{\prime} 22.0^{\prime \prime} \mathrm{N}, 80^{\circ} 43^{\prime} 48.7^{\prime \prime} \mathrm{E}$ \\
\hline & & MS27 & 1489 & $45^{\circ} 33^{\prime} 22.0^{\prime \prime} \mathrm{N}, 80^{\circ} 43^{\prime} 48.7^{\prime \prime} \mathrm{E}$ \\
\hline & & MS28 & 1489 & $45^{\circ} 33^{\prime} 22.0^{\prime \prime} \mathrm{N}, 80^{\circ} 43^{\prime} 48.7^{\prime \prime} \mathrm{E}$ \\
\hline & & MS29 & 1489 & $45^{\circ} 33^{\prime} 22.0^{\prime \prime} \mathrm{N}, 80^{\circ} 43^{\prime} 48.7^{\prime \prime} \mathrm{E}$ \\
\hline & & MS30 & 1489 & $45^{\circ} 33^{\prime} 22.0^{\prime \prime} \mathrm{N}, 80^{\circ} 43^{\prime} 48.7^{\prime \prime} \mathrm{E}$ \\
\hline & & MS31 & 1489 & $45^{\circ} 33^{\prime} 24.5^{\prime \prime} \mathrm{N}, 80^{\circ} 43^{\prime} 52.5^{\prime \prime} \mathrm{E}$ \\
\hline & & MS32 & 1489 & $45^{\circ} 33^{\prime} 24.5^{\prime \prime} \mathrm{N}, 80^{\circ} 43^{\prime} 52.5^{\prime \prime} \mathrm{E}$ \\
\hline & & MS33 & 1490 & $45^{\circ} 33^{\prime} 24.5^{\prime \prime} \mathrm{N}, 80^{\circ} 43^{\prime} 52.5^{\prime \prime} \mathrm{E}$ \\
\hline & & MS34 & 1489 & $45^{\circ} 33^{\prime} 18.9^{\prime \prime} \mathrm{N}, 80^{\circ} 43^{\prime} 59.7^{\prime \prime} \mathrm{E}$ \\
\hline & & MS35 & 1489 & $45^{\circ} 33^{\prime} 18.9^{\prime \prime} \mathrm{N}, 80^{\circ} 43^{\prime} 59.7^{\prime \prime} \mathrm{E}$ \\
\hline & & MS36 & 1509 & $45^{\circ} 33^{\prime} 20.7^{\prime \prime} \mathrm{N}, 80^{\circ} 44^{\prime} 00.0^{\prime \prime} \mathrm{E}$ \\
\hline & & MS37 & 1509 & $45^{\circ} 33^{\prime} 20.7^{\prime \prime} \mathrm{N}, 80^{\circ} 44^{\prime} 00.0^{\prime \prime} \mathrm{E}$ \\
\hline & & MS38 & 1509 & $45^{\circ} 33^{\prime} 20.7^{\prime \prime} \mathrm{N}, 80^{\circ} 44^{\prime} 00.0^{\prime \prime} \mathrm{E}$ \\
\hline & & MS39 & 1512 & $45^{\circ} 33^{\prime} 22.4^{\prime \prime} \mathrm{N}, 80^{\circ} 44^{\prime} 02.4^{\prime \prime} \mathrm{E}$ \\
\hline & & MS40 & 1512 & $45^{\circ} 33^{\prime} 20.7^{\prime \prime} \mathrm{N}, 80^{\circ} 44^{\prime} 00.0^{\prime \prime} \mathrm{E}$ \\
\hline & & MS41 & 1507 & $45^{\circ} 33^{\prime} 28.6^{\prime \prime} \mathrm{N}, 80^{\circ} 43^{\prime} 59.1^{\prime \prime} \mathrm{E}$ \\
\hline & & MS42 & 1507 & $45^{\circ} 33^{\prime} 28.6^{\prime \prime} \mathrm{N}, 80^{\circ} 43^{\prime} 59.1^{\prime \prime} \mathrm{E}$ \\
\hline & & MS43 & 1509 & $45^{\circ} 33^{\prime} 28.6^{\prime \prime} \mathrm{N}, 80^{\circ} 43^{\prime} 60.1^{\prime \prime} \mathrm{E}$ \\
\hline & & MS44 & 1190 & $45^{\circ} 32^{\prime} 59.9^{\prime \prime} \mathrm{N}, 80^{\circ} 41^{\prime} 47.9^{\prime \prime} \mathrm{E}$ \\
\hline
\end{tabular}

The concentration and quality of the obtained DNA were determined using the MaxLife Personal Gene Analyzer H100 (Barnaul, Russia), following the instruction of the manufacturer.

\section{Amplification and sequencing}

The primers ITS1 and ITS4 were used to amplify the ribosomal ITS-rDNA DNA fragment (White et al., 1990). The chloroplast DNA marker $\operatorname{trn} \mathrm{L}-\operatorname{trn} \mathrm{F}$ and the rps 16 intron were amplified using primers Tab- $c$ and Tab- $f$ (Taberlet et al., 1991) and primers rps16-f and rps16x2 (Oxelman et al., 1997). PCR was performed as described in Friesen, 2007 with a $20 \mu$ reaction mixture with $2 x$ HSTaqMix Red (PCRBio, Germany), where the mixture composi- tion included $1 \mu \mathrm{l}$ of direct and reverse primers, 10 $\mu \mathrm{l}$ of redmix, $8 \mu \mathrm{l}$ disH $2 \mathrm{O}$ as described.

Amplified products were checked on a $1.5 \%$ agarose gel stained with ethidium bromide before sending them to Microsynth Seqlab laboratory (Göttingen, Germany) for sequencing. The sequencing was performed with the same primers used for amplification. In some samples, two ITS fragments were amplified: $500 \mathrm{bp}$ (fungal ITS) and $600 \mathrm{bp}$ (ITS apples). The bands were separated on a $0.7 \%$ agarose gel, cut out and isolated using the PlantDNA Extraction Kit (Analytic Jena, Germany). Reamplification was performed with primers ITSsf and ITSsr (Blattner, 1999). Forward and reverse sequences were edited manually in CHROMAS Lite 
2.1 (Technelysium Pty Ltd) and combined into a single consensus sequence.

The sequences of all samples were aligned with CLUSTAL X (Jeanmougin et al., 1998), and the alignment subsequently manually corrected in MEGA7 (Kumar et al., 2016). A heuristic search with tree bisection reconnection (TBR) algorithm was conducted in PAUP 4.0b10 (Swofford, 2002). Bayesian phylogenetic analyses were performed using the software MrBayes 3.1.2 (Huelsenbeck, Ronquist, 2001). The sequence evolution model was evaluated by the Akaike Information Criterion (AIC) with the aid of jModeltest 3.7 (Darriba et al., 2012). Two independent runs with four Markov chains were run for 10 million generations, sampling every 100 trees. $25 \%$ of initial trees were discarded as burn-in. The remaining 250000 trees were combined into a single data set, and a majority-rule consensus tree was obtained. Bayesian posterior probabilities for that tree were calculated in MrBayes 3.1.23.

\section{ISSR analysis}

Fifteen ISSR markers were checked for suitability of further analysis using DNA from five samples. The amplification was carried out using a Biome- tra thermocycler (Professional Biometra, Germany) according to the standard ISSR-PCR method described in Bornet and Branchard (2001): $94{ }^{\circ} \mathrm{C}$ for 01:30 min $\left[94{ }^{\circ} \mathrm{C}\right.$ for $00: 40 \mathrm{~min} ., 45^{\circ} \mathrm{C}$ for $00: 45$ min., $72{ }^{\circ} \mathrm{C}$ for $01: 00 \mathrm{~min}$.] $\times 36,72{ }^{\circ} \mathrm{C}$ for $6 \mathrm{~min}$. using a mixture containing $1 \mu \mathrm{l}$ of DNA, 1 unit of Taq polymerase, $3 \mu \mathrm{l}$ of standard 10x buffer $2 \mu \mathrm{l}$ of dNTP, $1 \mu 1$ of $10 \mathrm{pM}$ primer, $1 \mu \mathrm{l}$ of DMSO, $20 \mu \mathrm{l}$ of double disH2O per $30 \mu 1$. Out of the 15 ISSR markers analysed, eight were polymorphic (Tab. 3).

The markers have a dominant type of inheritance, where polymorphism is determined by the presence or absence of a fragment. Each fragment was regarded as a single locus. The band were scored independently as either present (1) and absent (0) and summarised in a matrix. Only clear bands with good repeatability from 500 to $3500 \mathrm{bp}$ were recorded. A principal component analysis (PCA) was carried out using the software R 3.4.2 (R Development Core Team 2008). The proportion of polymorphic loci $(\mathrm{P})$ corresponding to the level of genetic variability was calculated. Using the MEGA 7 program (Kumar et al., 2016), a dendrogram was constructed based on the UPGMA genetic distance (Sokal, Michener, 1958).

Table 3

Characteristics of ISSR-PCR Markers

\begin{tabular}{|c|c|c|c|c|}
\hline Primer & Primer Sequences & $\begin{array}{l}\text { Total Number of } \\
\text { Fragments }\end{array}$ & $\begin{array}{l}\text { Polymorphic } \\
\text { fragments }\end{array}$ & Polymorphism \\
\hline $\mathrm{GR}_{215}$ & $(\mathrm{CA})_{6} \mathrm{GT}$ & 22 & 21 & $95.5 \%$ \\
\hline ISSR-1 & $(\mathrm{AC})_{8} \mathrm{~T}$ & 14 & 13 & $95.5 \%$ \\
\hline $\mathrm{GR}_{212}$ & $(\mathrm{CT})_{8} \mathrm{TG}$ & 12 & 10 & $83.3 \%$ \\
\hline $\mathrm{HB}_{10}$ & $(\mathrm{GA})_{6} \mathrm{GG}$ & 19 & 15 & $78.9 \%$ \\
\hline $\mathrm{HB}_{12}$ & $(\mathrm{CAC})_{3} \mathrm{GC}$ & 17 & 17 & $100 \%$ \\
\hline $\mathrm{UBC}_{828}$ & (TG) ${ }_{7} \mathrm{TA}$ & 15 & 14 & $95.5 \%$ \\
\hline MAO & $(\mathrm{CTC})_{4} \mathrm{RC}$ & 25 & 23 & $92 \%$ \\
\hline $\mathrm{UBC}_{809}$ & $(A G)_{8} G$ & 10 & 6 & $60 \%$ \\
\hline \multicolumn{4}{|c|}{ Average level of polymorphism } & $87.6 \%$ \\
\hline
\end{tabular}

\section{Results and discussion}

\section{Sequencing}

The ITS region, including the ITS1 gene, 5.8S and ITS2, was amplified using the external primers ITS1 and ITS4 (White et al., 1990) in 15 samples of the Sievers apple tree (12 clone-varieties from the MBG collection and one sample from each studied natural populations). All the ITS sequences obtained turned out to be almost identical, only some sections showed the presence of at least two copies in the genome of the $M$. sieversii, which was also confirmed by the analysis of the sequences we obtained with sequences published in the nucleotide Genbank. We built a phylogenetic ITS tree with all the sequences we obtained with the inclusion of all ITS related apple sequences published in the Genbank (NCBI) (Fig. 2). The ITS alignment of sequences includes 578 features, 507 of them turned out to be constant, 42 variable signs of parsimony are not informative, and only 29 signs are parsimony informative. The 10000 most economical trees had a length of 110 steps, a consistency index of CI $=0.7822$ and a retention index of $\mathrm{RI}=0.9027$. The most suitable model for ITS, chosen by AIC вј Modeltest 2.1.7 was GTR + I + G. In our tree, all the sequences of M. sieversii form monophyletic clade, with not a very high support (bootstrap $53 \%$, Bayesian prob- 
ability 0.87 (Fig. 3). ITS sequences are included into the same clade from other apple species - Malus domestica Borkh. (6 samples) M. orientalis Uglitzk. ex Juz.- AF186498, M. asiatica Nakai - AF186494), which confirms the hybridogenic origin of the cultivated apple tree from the Sievers apple tree (Luby et al., 2001; Forte et al., 2002). It is also possible that there is a closely related relationship of $M$. orientalis and M. asiatica with $M$. sieversii, confirming the results obtained by Nikifirova et al. (2013), where in the phylogenetic tree, constructed on the basis of complete genome sequences of chloroplast DNA of Malus genus, these species are also members of the same clade with the Sievers apple tree.

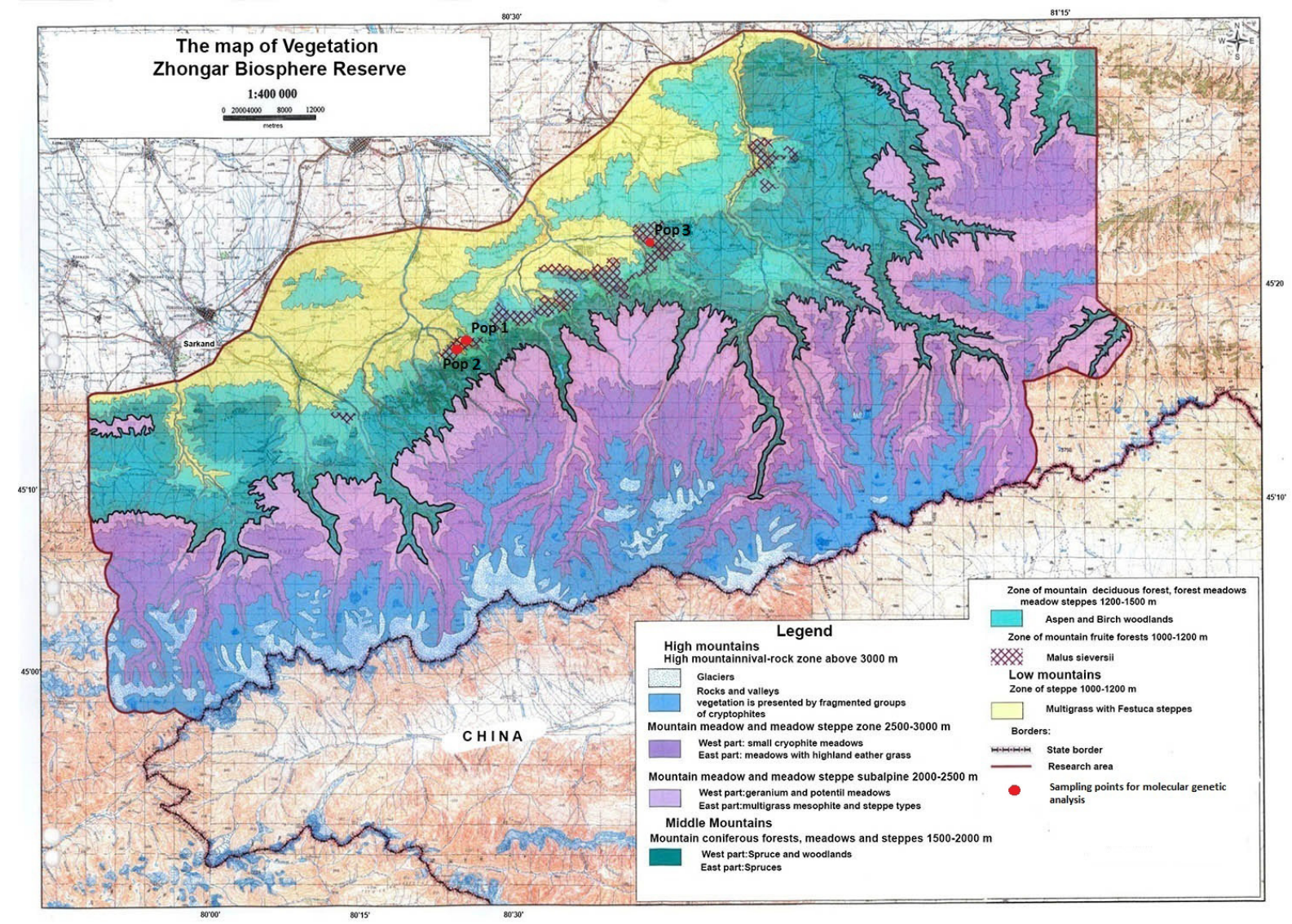

Fig. 2. Map of Malus sieversii sampling locations: Pop 1 - reserve "Pikhtovaya"; Pop 2 - reserve "Mushabay"; Pop 3 - reserve "Krutoye".

The chloroplast rps16 intron was sequenced in 18 samples (10 clone-varieties from the MBG collection and 8 samples from natural populations). All obtained sequences were absolutely identical. The sequences of $\operatorname{trn} \mathrm{L}-\operatorname{trn} \mathrm{F}$ were also obtained in 5 samples of Sievers apple tree (2 samples of the variety clone from MBG: TM5 and TM7 and one sample from natural populations). All sequences also turned out to be identical. The nucleotide sequences obtained by us were sent for publication to Genbank (ITS LR588511-LR588525; trnL in-

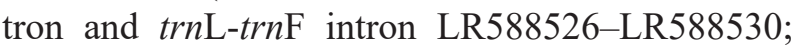
rps16 intron MK994749-MK994766). Thus, our data are fully consistent with the findings of Zhang et al. (2015), which sequenced 10 chloroplast DNA fragments $(p s b \mathrm{~A}-t r n \mathrm{H}, \operatorname{trn\mathrm {S}}-t r n \mathrm{G}, \operatorname{trn} \mathrm{L}-t r n \mathrm{~F}$, atp $\mathrm{B}-$ $r b c \mathrm{~L}, r p l 20-r p s 12, p s b \mathrm{~B}-p s b \mathrm{H}, r p s 16-t r n \mathrm{Q}, n d h \mathrm{~F}-$ rpl32, $\operatorname{trn} \mathrm{D}-\operatorname{trn} \mathrm{T}, \quad r p l 16$ and $y c f 6-p s b \mathrm{M})$ in the $M$. sieversii populations on the southern macroslope of the Dzungar Alatau in Western China, and did not reveal any differences. The molecular genetic research and sequencing of the DNA fragments of M. sieversii clone-varieties of the Dzungar population from the MBG collection and samples taken from the natural population was performed for the first time.

\section{ISSR-PCR analysis}

ISSR-PCR markers were used to study the intraspecific variability of the $M$. sieversii. As a result of using 8 ISSR-PCR markers (Tab. 3), 124 polymorphic ISSR fragments from 134 analyzed amplicons were identified on 44 samples. Depending on the primer, 10 to 25 amplified DNA fragments 


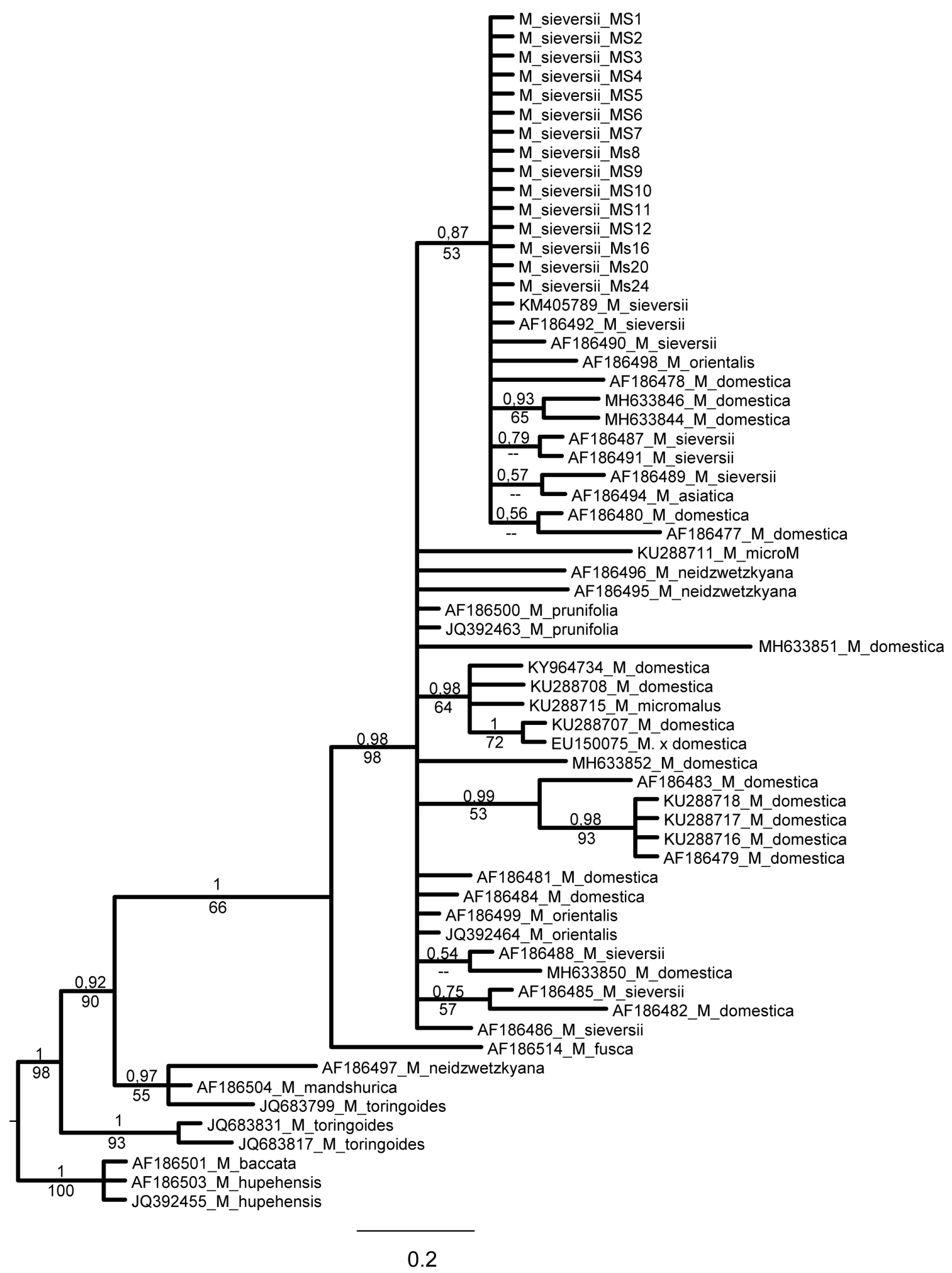

Fig. 3. Bayesian tree based on ITS sequences of Malus sieversii and sequences of other apple species published in the Genebank. 


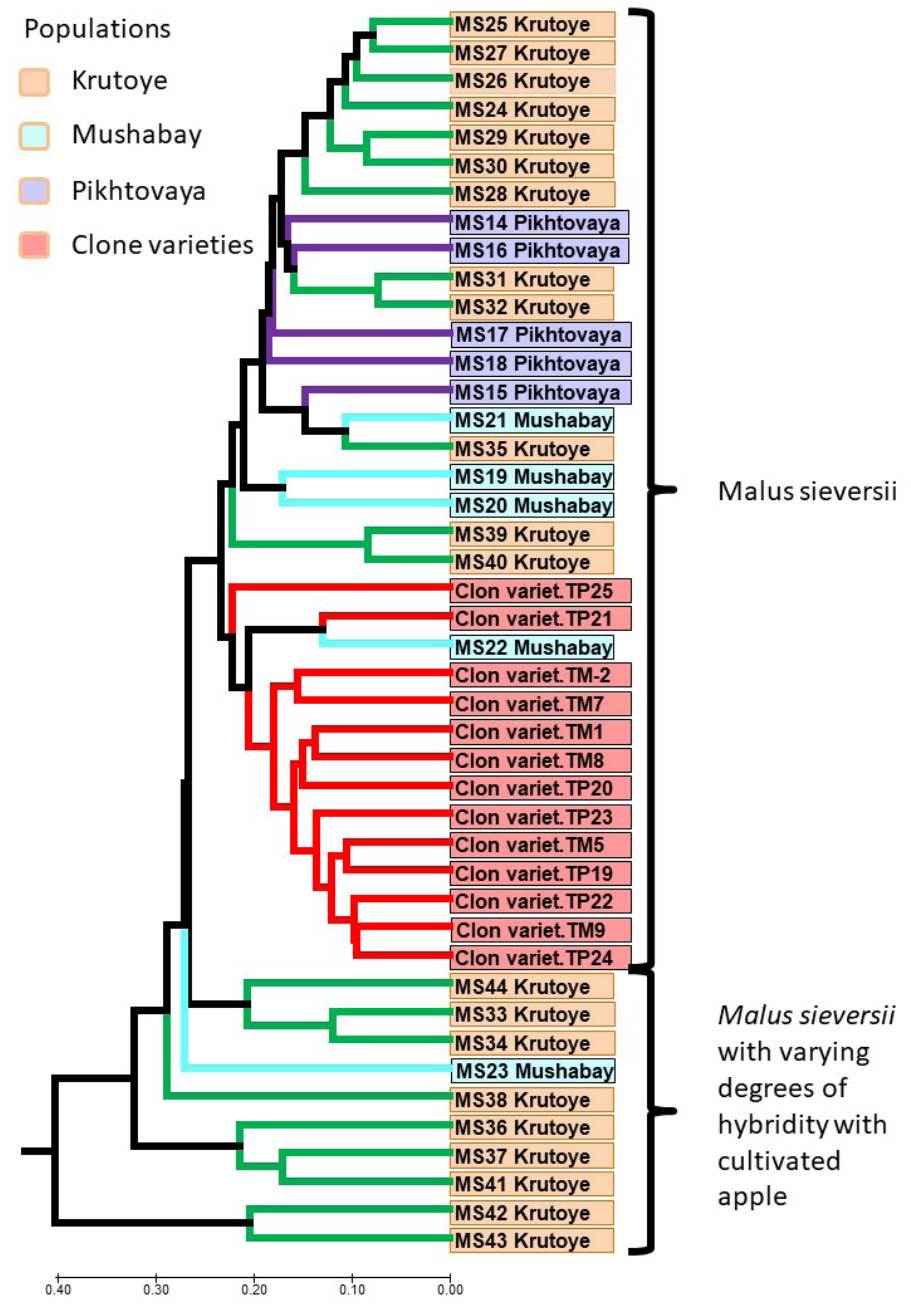

Components 1 and 2

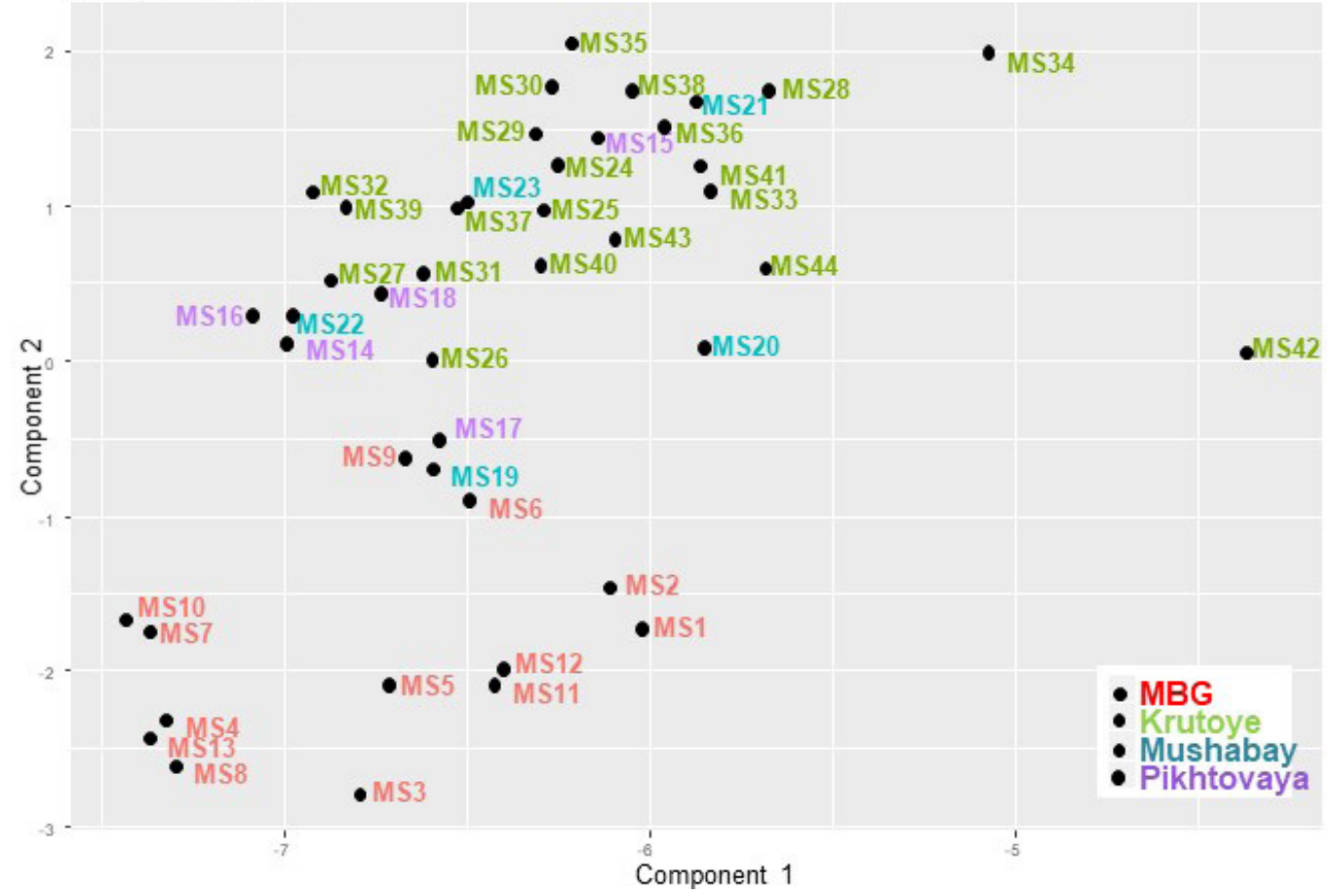

Fig. 4. UPGMA cluster analysis and main coordinate analysis (PCA) for 44 samples of Malus sieversii based on the ISSR matrix: a - dendrogram constructed using the UPGMA method based on K2P coefficient (Kimura, Ohta, 1972); $\mathrm{b}$ - distribution of the studied samples using the main coordinates analysis (PCA). 
(bands) were detected, the sizes of the fragments varied from 500 to $3500 \mathrm{bp}$. The MAO primer identified the maximum number of fragments. The minimum number of fragments as well as the smallest number of polymorphic loci $(60 \%)$ is marked using primer UBC809. The largest number of polymorphic loci of the analyzed samples was found with the UC828, HB12, GR215 primers, which constituted $95.5-100 \%$ of polymorphism. On average, the level of ISSR loci polymorphism, identified using 8 primers was $87.6 \%$. (Tab. 3). ISSR marking of clone-varieties revealed 115 fragments, of which 91 were polymorphic $(\mathrm{P}=0.791)$. Analysis of the ISSR spectrum of the natural population of the $M$. sieversii revealed 131 amplified sections of DNA, of which 121 were polymorphic $(\mathrm{P}=0.923)$.

The results obtained indicate a high molecular genetic polymorphism of the studied samples and confirm the promising nature of prospects of using ISSR-PCR markers for establishing genetic differences within the species.

In this study, a dendrogram constructed using an unweighted pair-group method using arithmetic means (UPGMA) showed the separation of all the studied samples into 2 clusters (Fig. 4a). In the first cluster, were grouped both the samples of $M$. sieversii from the natural population, as well as clone-varieties from the MBG collection, indicating that these forms are similar in terms of genotype. No clustering was found depending on the geographical distance, which is explained by the geographically close location of natural populations and selection of the scion for creating clone-varieties from the same natural reserves. The subsequent division into 2 subclusters with a separate clone-variety indicates their reconstructed genome. Previously it was stated that all the studied clone-varieties were created by budding grafts selected from the Dzungar Alatau into wild apple roots. The fact that clone-varieties are not grouped among populations from which grafts were collected can most likely be explained by the genetic impact of the graft (Lewsey et al., 2016). Only one sample from the Mushabay site was among the clone-varieties, possibly related to them.

Cluster 2 combined samples of $M$. sieversii of presumably hybrid origin. Samples from the lower part of the "Krutoye" population (Ms44), samples growing close to the carriageway (Ms33,
Ms34, Ms36 - Ms38, Ms41 - Ms43) and only one sample from the population were mainly included Mushabay (Ms23). Similar results were obtained by Omasheva et al. (2018) with the use of SSR markers, which confirm the probable hybridization in natural populations of wild apple trees with cultivars depending on the height of the given population.

Analysis of the main coordinates (PCA) of the studied populations shows a slightly different distribution of the samples compared to the UPGMA dendrogram. Here, only 2 samples from the "Krutoye" Dzungar Alatau population were separated from the common cloud (Ms34 and Ms42), all other studied samples form a more or less unbroken cloud, in which all the clone-varieties are grouped together. According to PCA analysis, samples from natural populations are partially mixed, which indicates genetic exchange between these populations (Fig. 4b).

\section{Conclusion}

According to the results of this study (ITSrDNA, plastid fragments of the trnL-trnF and rps 16 intron), the Sievers apple tree forms a monophyletic clade. The similarity of nucleotide sequences within a species obtained by sequencing the ribosomal and chloroplast DNA fragments of the studied samples suggests that there is an active genetic exchange between the populations of the species. The dendrogram constructed using the UPGMA and PCA analyzes showed that all the studied clone-varieties were $M$. sieversii and have a genotype similar to the forms from the natural populations of the Dzungar Alatau, but an uneven genetic distribution of the studied samples was found, indicating an artificial construction of the genotype of the clone-varieties. As a result of the use of 8 ISSR-PCR markers, a high level of molecular genetic polymorphism was found within the species $M$. sieversii. The samples studied have a wide range of variability in both in situ and ex situ conditions, which is explained by their biological and ecological features.

\section{Acknowledments}

We thank Msc Tobias Herden (University of Osnabrueck) for his assistance in the analysis with program $\mathrm{R}$ and critical reading of the manuscript. This work was supported from Al-Farabi Kazakh National University for the first author.

\section{REFERENCES}

Blattner $\boldsymbol{F}$. $R$. 1999 . Direct amplification of the entire ITS region from poorly preserved plant material using recombinant PCR. Biotechnology 27: 1180-1185. DOI: 10.2144/99276st04 
Bornet B., Branchard M. 2001. Nonanchored Inter Simple Sequence Repeat (ISSR) markers: reproducible and specific tools for genome fingerprinting. Plant Mol Biol Rep. 19: 209-215.

Darriba D., Taboada G. L., Doallo R., Posada D. 2012. "jModelTest 2: more models, new heuristics and parallel computing". Nature Methods 9(8): 772.

Dzhangaliev A. D. 1977. Dikaya yablonya Kazakhstana [The wild apple of Kazakhstan]. Nauka, Alma-Ata, 280 pp. [In Russian]. (Джсангалиев А. Д. Дикая яблоня Казахстана. Алма-Ата: Наука, 1977. 280 с.).

Dzhangaliev A. D. 2003. The wild apple tree of Kazakhstan. Hort. Rev. 29: 65-304.

Dzhangaliyev A. D., Napina L. I., Salova T. N., Uvarova Ye. I. 1981. Malus sieversii (Ledeb.) M. Roem. In: Red Data Book of Kazakh SSR. Rare and endangered species of animals and plants. Part 2. Plants. Publishing house "Nauka" of Kazakh SSR, Alma-Ata, 98 p. [In Russian]. (Джсаналиев А. Д., Напина Л. И., Салова Т. Н., Уварова E. И. Malus sieversii (Ledeb.) М. Roem. // Красная книга Казахской ССР. Редкие и находящиеся под угрозой исчезновения виды животных и растений. Ч. 2. Растения. Алма-Ата: Изд-во «Наука» Казахской ССР, 1981. С. 98).

Dzhangaliev A. D., Salova T. N. 2007. Unique and global knowledge of the apple forest gene pool of Kazakhstan. Doklady Nastionalnoy akademii nauk Respubliki Kazakhstan [Reports of RK NAS] 5: 41-47 [In Russian]. (Джканалиев А. Д., Салова Т. Н. Уникальное и глобальное значение генофонда яблоневых лесов Казахстана // Доклады НАН РК, 2007. № 5. С. 41-47).

Forsline P. L., Aldwinckle H. S., Dickson E. E., Hokanson S. C. 2003. Collection, maintenance, characterization, and utilization of wild apples from central Asia. Hort. Rev. 29: 1-61.

Forte A. V., Ignatov A. N., Ponomarenko V. V., Dorokhov D. B., Savelyev N. I. 2002. Phylogeny of the Malus (apple tree) species, inferred from the morphological traits and molecular DNA analysis. Russian Journal of Genetics 38(10): 1150-1160.

Friesen N. 2007. Molekulyarnyye metody, ispolzuyemyye v sisematike rasteniy [Molecular methods using in plant taxonomy]. Azbuka, Barnaul, 33-34 pp. [In Russian]. (Фризен Н. Молекулярные методы, используемые в систематике растений. Барнаул: АзБука, 2007. С. 33-34).

Gupta M., Chyi Y-S., Romero-Severson J., Owen J. L. 1994. Amplification of DNA markers from evolutionarily diverse genomes using single primers of simple-sequence repeats. Theor. Appl. Genet. 89: 998-1006. DOI: 10.1007/ BF00224530

Hokanson S. C., Szewc-McFadden A. K., Lamboy W. F., McFerson J. R. 1998. Microsatellite (SSR) markers reveal genetic identities, genetic diversity and relationships in a Malus $\times$ domestica Borch. core subset collection. Theor. Appl. Genet. 97: 671-683. DOI: 10.1007/s001220050943

Huelsenbeck J. P., Ronquist F., Nielsen R., Bollback J. P. 2001. Bayesian inference of phylogeny and its impact on evolutionary. Biology Science 294: 2310-2314.

Hurka G., Friesen N., German D., Franzke A., Neuffer B. 2012.'Missing link' species Capsella orientalis and Capsella thracica elucidate evolution of model plant genus Capsella (Brassicaceae). Molecular Ecology 21: 12231238. DOI: $10.1111 / \mathrm{j} .1365-294 X .2012 .05460 . x$

Isayev E. B. 2014. Malus sieversii (Ledeb.) M. Roem. In: Red Data Book of Kazakhstan. Vol. 2. Part 1. Plants. Ed. by I. O. Baitulin. Almaty, 52 p. [In Russian]. (Исаев Е. Б. 2014. Malus sieversii (Ledeb.) M. Roem. // Красная книга Казахстана. Т. 2. Ч. 1. Растения. Алматы, 2014. С. 52).

IUCN. URL: https://www.iucn.org (Accessed 05 November 2015).

Jeanmougin F., Thompson J. D., Gouy M., Higgins D. G., Gibson T. J. 1998. Multiple sequence alignment with Clustal X. Trends Biochem. Sci. 23: 403-405. DOI: 10. 1016/S0968-0004(98)01285-7

Juniper B., Mabberley D. J. 2006. The story of the apple. Timber Press, Portland, 511 pp.

Kimura M., Ohta T. 1972. On the stochastic model for estimation of mutational distance between homologous proteins. Journal of Molecular Evolution 2: 87-90.

Kumar S., Stecher G., Tamura K. 2016. MEGA7: Molecular Evolutionary Genetics Analysis version 7.0 for bigger datasets. Molecular Biology and Evolution 33: 1870-1874. DOI:10.1093/molbev/msw054

Kutsev M. G. 2009. Fragmentnyy analiz DNK rasteniy: RAPD, DAF, ISSR [Fragment analysis of Plant DNA: $R A P D, D A F, I S S R$ ]. Artika, Barnaul, 164 pp. [In Russian]. (Куцев М. Г. 2009. Фрагментный анализ ДНК растений: RAPD, DAF, ISSR. Барнаул: Артика, 2009. 164 с.).

Ledebour C. F. 1830. Flora Altaica. Vol. 2. G. Geimeri, Berlin, 464 pp.

Lewsey M. G., Hardcastle T. J., Melnyk C. W., Molnar A., Valli A., Urich M., Nery J.., Baulcombe D., Ecker J. 2016. Mobile small RNAs regulate genome-wide DNA methylation. PNAS 18: 1-10. DOI: 10.1073/pnas.1515072113.

Luby J., Forsline P., Aldwinckle H., Bus V., Geibel M. 2001. Silk road apples-collection, evaluation, and utilization of Malus sieversii from Central Asia. HortScience 36: 225-231.

Nikifirova S., Cavalieri D., Velasco R., Goremykin V. 2013. Phylogenetic analysis of 47 chloroplast genomes clarifies the contribution of wild species to the domesticated apple maternal line. Mol. Biol. Evol. 30 (8): 1751-1760.

Olonova M., Feugey L., Gabrielyan I., Zhang X.-G., Tenaillon M. I., Giraud T. 2012. New insight into the history of domesticated apple: secondary contribution of the European wild apple to the genome of cultivated varieties. PLoS Genet. 8: e1002703. DOI: 10.1371/journal.pgen.1002703 
Omasheva M., Chekalin S. V., Ryabushkina N. A., Galiakparov N. N. 2015. Evaluation of the molecular genetic diversity of Malus Sieversii population in Dzungarian Alatau and Tarbagatay Mountains. Biotechnology. Theory and Practice 1: 26-34 [In Russian]. (Омашева М. Е., Чекалин С. В., Рябушкина Н. А., Галиакиаров Н. Н. Оценка молекулярно-генетического разнообразия популяций Malus sieversii Джунгарского Алатау и Тарбагатая // Биотехнология. Теория и практика, 2015. № 1. С. 26-34). DOI: 10.11134/btp.1.2015.3

Omasheva M., Flachowsky H., Ryabushkina N., Pozharskiy A., Galiakparov N., Hanke M. 2017. To what extent do wild apples in Kazakhstan retain their genetic integrity? Tree Genetics \& Genomes 13: 52. DOI: 10.1007/s11295017-1134-z

Omasheva M., Pozharsky A. S., Smailov B. B., Ryabushkina N. A., Galiakparov N. N. 2018. Genetic diversity of apple cultivars growing in Kazakhstan. Russian Journal of Genetics 54 (2): 176-187.

Oxelman B., Lidén M., Berglund D. 1997. Chloroplast rps 16 intron phylogeny of the tribe Sileneae (Caryophyllaceae). Plant Syst. Evol. 206: 393-410. DOI: 10.1007/BF00987959

Richards C. M., Volk G. M., Reilley A. A., Henk A. D., Lockwood D., Reeves P. A., Forsline P. L. 2009. Genetic diversity and population structure in Malus sieversii, a wild progenitor species of domesticated apple. Tree Genet. Genomes 5: 339-347. DOI: 10.1007/s11295-008-0190-9

Robinson J. P., Harris S. A., Juniper B. E. 2001. Taxonomy of the genus Malus Mill. (Rosaceae) with emphasis on the cultivated apple, Malus domestica Borkh. Plant Syst. Evol. 226: 35-58. DOI:10.1007/s006060170072

Roemer M. J. 1847. Familiarum naturalium regni vegetabilis Synopses monographicae. Fasc. III. Rosiflorae. Vimariae, Landes-Industrie-Comptior, 314 pp. DOI: 10.5962/bhl.title.49482

Sievers J. A. C. 1796. Briefe aus Sibirien. St. Petersburg. URL: http://www.deutschestextarchiv.de/book/view/ siever_briefe_1796

Sitpaeva G. T., Vesselova P. V., Gemedjieva N. G., Grudzinskaya L. M. 2014. Comprehensive studies of wild relatives of cultivated plants of the Western Tien Shan. In: Trudy Instituta botaniki i fitointrodukstii [Proceedings of the Institute of Botany and Phytointroduction]. Almaty, 194 pp. [In Russian]. (Ситпаева Г. Т., Веселова П. В., Гемеджиева Н. Г., Грудзинская Л. М. Комплексные исследования диких сородичей культурных растений Западного Тянь-Шаня // Тр. Инст. ботаники и фитоинтродукции. Алматы, 2014. 194 с.).

Smirnov S., Friesen N. 2006. Brachanthemum baranovii (Asteraceae), a sample showing the utility of moleculargenetic analysis for revealing the hybrids. In: Problems of Botaniy of South Siberia and Mongolia: Proceeding of $5^{\text {th }}$ International Scientific-Practical Conference (Barnaul, 21-23 November 2006). Barnaul, 256-258 pp. [In Russian]. (Смирнов С. В., Фризен Н. В. 2006. Использование молекулярно-генетического анализа для выявления гибридов на примере Brachanthemum baranovii (Asteraceae) // Проблемы ботаники Южной Сибири и Монголии: Материалы V Междунар. науч.-практ. конф. (Барнаул, 21-23 ноября 2006 г.). Барнаул, 2006. С. 256-258).

Sokal R. R., Michener C. D. 1958. A statistical method for evaluating relationships. University of Kansas Science Bulletin 38: 1409-1448.

Swofford D. L. 2002. PAUP*. Phylogenetic analysis using parsimony ("and other methods). Version 4.0 beta version. Sinauer Associates, Sunderland, Massachusetts, 144 pp.

Taberlet P., Gielly L., Pautou G., Bouvet J. 1991. Universal primers for amplification of three non-coding regions of chloroplast DNA. Pl. Mol. Biol. 17: 1105-1109.

Vavilov N. I. 1931. The wild relatives of fruit trees of the Asian part of the USSR and Caucasus and the problem of the origin of fruit trees. Trans. Apple Bot. Gene Breed. 263):132-134.

Volk G. M., Richards C. M., Henk A. D., Reilley A. A., Miller D. D., Forsline P. L. 2009. Novel diversity identified in a wild apple population from the Kyrgyz Republic. Hort. Science 44: 516-518. DOI: 10.21273/HORTSCI.44.2.516

Volk G. M., Richards C. M., Reilley A. A., Henk A. D., Forsline P. L., Aldwinckle H. S. 2005. Ex situ conservation of vegetatively propagated species: development of a seed-based core collection for Malus sieversii. J. Amer. Soc. Hort. Sci. 130: 203-210. DOI:10.21273/JASHS.130.2.203

White T. J., Bruns T., Lee S., Taylor J. 1990. Amplification and direct sequencing of fungal ribosomal RNA genes for phylogenetics. In: PCR Protocols: a guide to methods and applications. Academic Press, New York, USA, 315-322 pp. DOI: 10.1007/BF00224530

Yan G., Long H., Song W., Chen R. 2008. Genetic polymorphism of Malus sieversii populations in Xinjiang, China. Genet. Resources Crop Evol. 55: 171-181. DOI: 10.1007/s10722-007-9226-5

Zhang C., Chen X., He T., Liu X., Feng T., Yuan Z. 2007. Genetic structure of Malus sieversii population from Xinjiang, China, revealed by SSR markers. Journal of Genetics and Genomics 34: 947-955. DOI:10.1016/S16738527(07)60106-4

Zhang H., Zhang M., Wang L. 2015. Genetic structure and historical demography of Malus sieversii in the Yili Valley and the western mountains of the Junggar Basin, Xinjiang, China. J Arid Land. 7(2): 264-271. DOI: 10.1007/ s40333-014-0044-2

Zhou Z. Q., Li Y. N. 2000 The RAPD evidence for the phylogenetic relationship of the closely related species of cultivated apple. Genet Res Crop Evol. 47:353-357. DOI: 10.1023/A:1008740819941 